\title{
MANAGEMENT OF AN INDUSTRY STANDARD CLASS IN VOCATIONAL HIGH SCHOOLS
}

\author{
Suroto ${ }^{1}$, Nguyen Tien Hung ${ }^{2}$ \\ ${ }^{1}$ Department of Industrial Automation, SMK Negeri 2 Depok Sleman Yogyakarta, Indonesia \\ ${ }^{2}$ Control Engineering Division, NamDinh University of Technology Education, Vietnam \\ Email: pakroto313@gmail.com
}

\begin{abstract}
To remove a growing gap between students' skills received in vocational high schools and real demands in the workforce, industries should be actively involved not only as external users but to work in curriculum development and learning evaluation. This study describes the process of planning, implementation, and supervision of an industry standard class resulted from collaboration between the school and the industry. This study was a qualitative study using data collection techniques of interviews, observation and documentation. The results revealed (1) the industry and the school were partners in planning the industry standard class including development of curriculum, facilities, infrastructure, teachers, and materials, (2) implementation of the class included theoritical and practical learning, and industry practices, (3) supervision was performed by the industry partner administrating industry standard competency tests, and (4) management of the class consisted of three sequenced stages namely selection of students in the third semester, implementation of industry standardized teaching and learning process from the third semester to the sixth semester, and a competency test in the sixth semester.
\end{abstract}

Keywords: industry standard class, management, vocational high school

\section{INTRODUCTION}

Human Resources have a significant role in the economic development of a country. The industry excellence of a country is determined by the quality of skilled labor directly involved in the production process (Djoyonegoro, 1988) thus the direct involvement of skilled labor gives a direct impact on industry productivity and economic growth of a country.

Vocational High School (VHS) also known as Sekolah Menengah Kejuruan (SMK) is designed to concern with human resources development to cope the requirements of fast developing market (Wibowo, 2016). The Indonesian government expects SMK as vocational education institutions according to the explanation of the National Education System law Number 20 Year 2003 Article 15, to be a secondary education that prepares learners primarily to work in certain areas of expertise. SMK as stated in the regulation of the Minister of National Education of the Republic of Indonesia Number 22 Year 2006 is also expected to improve intelligence, knowledge, personality, noble character, and skills of learners to live independently and follow further education in accordance with the vocational program (Ministry of National Education, 2013). Therefore SMK is supposed to play their pivotal role in supplying skilled manpower for the industries.

But at the same time, the Institute of Management Development (IMD), a leading business education institution in Switzerland reveals that the rank of Indonesian talented and skilled workers fell 16 ratings from the $25^{\text {th }}$ rank in 2014 to the $41^{\text {st }}$ rank in 2015 (Kompas, 2015). In addition, the report from the Indonesian Central Bureau of Statistics in 2015 states that the open unemployment rate of vocational high school graduates from year to year is increasing. The open unemployment rate of vocational high school graduates in August 2015 even reached $12.65 \%$ or approximately 96.1400 people.

The preparation of qualified workers graduated from SMK is often faced with the problem of the extent to which students are equipped with knowledge and skills in 
accordance with the real conditions in the world of business and industries. Soeprijanto (2010) emphasizes that building high-quality education needs to be conducted comprehensively covering various aspects such as (1) teachers, (2) the provision of physical facilities and infrastructure, and (3) curriculum and learning system. In the other hand, the real conditions of vocational education generally are: (a) in the aspect of the teaching staffs, many vocational teachers have not updated their skills to cope with the development of science and technology, consequently most of the education in VHS is implemented below the standards of national education thus the graduates are not equipped with adequate competence, (b) the unavailability of feasible and modern workshops and laboratories, and the weak relation between VHS and the world of industry thus the graduates are not adaptive to the world of work, and (c) The world of industry is not fully involved in the curriculum thus lessons in the classroom do not fit with the competencies required by the world of industry. These issues cause a wide gap between competencies developed in the educational process and the needs of the industry world.

For that matter, National education standards are established by the government to be a reference for curriculum development, educational personnels, learning facilities and infrastructure, management and finance of an educational institution. The national standard of education is a minimal criterion of the national education system aimed to maintain the quality standard of educational institutions. However, to improve the quality of the educational unit, other standards are allowed to be used after the national standards are completed. One of the VHS education system standards are standards created by the world of business and industries. The industry standards are used systematically in the learning management or classroom management.

The industry standards are created by partnerships between the school and the industries. The partnerships between vocational education institutes and the industries are essential and beneficial. Rochmadi (2016) suggests that the technological development is difficult to be adopted by the schools thus the schools need to establish partnerships with the world of work that is quicker in responding technological development because of the work efficiency and effectiveness demands. Mulyadi \& Sumarto (2009) also claim that the industries must take more responsibility in vocational education. The industries and the government should share the role equally.

SMK PIRI 1 Yogyakarta is one of the vocational high schools that can be a role model of building the strong partnership with the industry. The school works collaboratively with the industry to co-organize an industry standard class. This class is aimed to help better prepare the students enrolled in the class to work effectively in the industries, particularly, they are prepared for real work environment in the industry partner. The school are partners with PT. Yamaha Motor Indonesia, a manufacturer of motorcycles, to develop a Yamaha Special Class. This class is focused on producing graduates of SMK PIRI 1 Yogyakarta equipped with competence in accordance with Yamaha industry standards. The development of an industry standard class in SMK PIRI 1 Yogyakarta certainly requires a good management that can be referred by other schools. Research on planning, implementation, supervision of the model is therefore crucial.

\section{METHOD}

This study was designed with a qualitative approach, which was digging as much data as possible from the object of the study. This study did an in-depth examination of the management of an industry standard class and defined the model of the class. Several data collection techniques were used namely interviews, direct observation, and document scrutiny. The interviews were focused on information to support the study by opinions and facts in the field. The interviews were 
directed with predetermined interview guidelines to school policyholders and school management implementers including principals, vice principals, heads of motorcycle engineering expertise classes and Yamaha special class teacher representatives.

The researcher did a passive participative observation to understand the process and the context of the interviews. The subjects related to the organization of the industry standard class and relevant matters to provide additional data on the results of the interview were observed in details. Patton in Poerwandari (1998) states that the purpose of observation is to describe the settings studied, the activities that take place, the people involved in the activity, and the meaning of the events seen from their perspective in the observed event. The observational data were collected by observing the physical condition, the activities, the learning activities, and the student activities which are the parts of the implementation of the class. In addition, document scrutiny was conducted to support the results of interviews and observations. The data collection instruments consisted of data source grids, interview guidelines, observation guidelines, document scrutiny guidelines, cameras and recording devices.

The data analysis was performed in several stages including data reduction, data presentation, and conclusions. The data from the result of interviews, observation and documentation were classified, directed and organized in three components of planning, implementation and supervision. The data then were made as the basis for drawing a conclusion that was still open, general, and then were turned be a specific or detailed conclusion.

The validity of the research data was based on four criteria of credibility, namely transferability, dependability, and confirmability (Moleong, 2016). The data credibility testing in this study was conducted with triangulation of data sources and methods. Transferability in qualitative research was achieved by detailed description. Dependability was conducted to overcome errors in the conceptualization of research plans, data collection, interpretation of findings and reporting of research results. To satisfy the dependability in this study, the supervisors were invited to be dependent auditors in the research management.

Confirmability is required to know whether the data obtained objectively or not. It was performed by confirming the data with the informants or experts. All informants in this study were requested to sign the transcripts of interview results. This activity was carried out jointly with the dependability auditing. The difference was if the dependability auditing is aimed at assessing the process through which the study was conducted, while the auditing of confirmability was to ensure the linkage between data, information, and interpretation as outlined in the report and supported by the available materials.

\section{RESULTS AND DISCUSSION}

The curriculum used in the industry standard class is a competency-based curriculum. All curriculum activities are organized to achieve the competency goals demanded by the work field in accordance with the expectations, demands and standards of the industry partner. It is expected that students will achieve competencies tailored to the competence of industry specification standards. Therefore the role of the industry partner in the preparation of the curriculum is very dominant. The curriculum applied to the Yamaha special class in SMK PIRI 1 Yogyakarta is a curriculum resulted from the combination of a Light Vehicle Engineering curriculum with a Yamaha education and training curriculum.

The students selection is also a very important stage because it is aimed to recruit students with high interest and high academic ability and skills, thus they can achieve the educational goals. Minimum requirements are designed that include the average scores of report cards, attendance records, achievements 
and student personalities. Furthermore, the selection of academic potential is conducted using a written test. Students who pass the selection can perform the interview test. The students are also required to provide the approval from parents or guardians and the statement of ability to follow further education. The students who do not pass the selection will follow the regular classes.

Since facilities and infrastructure in teaching and learning activities have a very important role that will greatly support students in mastering the competencies, the facilities and infrastructure of the class are standardized by Yamaha Motor Kencana Indonesia. Yamaha standard classroom is a classroom with a capacity of 20 students painted by 3 different colors. The floor is light gray. The line between the floor and the wall is light gray with the height of 1.35 meters. The wall is white with the height above 1.35 meters. If the floor uses ceramic, it is allowed not to change the color of the classroom. It is also required to provide a cut engine and spare parts in the classroom.

The Yamaha Special Class classroom in SMK PIRI 1 Yogyakarta has a capacity of 30 students with the size of $10 \times 8$ meters painted by 3 different colors according to the standard. A Yamaha standard practicum classroom has a minimum size of $5 \times 10$ meters with 4 pit areas. The practice room should be painted with 4 different color parts. The first part is the line between the floor and the wall which is in light gray with a height of 1.35 meters. The second part is the wall which is white with a height above 1.35 meters. The third part is the pit area colored with dark gray. While the floor is in light gray. If the classroom use ceramic, it is allowed not to change the color of the classroom. The Yamaha Special Class classroom in SMK PIRI 1 Yogyakarta has a size of $12 \times 8$ meters with 4 pit areas painted by 4 different colors according to the standard. The classroom is also equipped with 4 bike lif, a smoke suction machine and a blower.

Yamaha practice equipment standards are grouped into 3, namely: (a) Yamaha Workshop
Standard equipment, (b) FI Diagnostic Fuel Injection or Data Logger equipment, and (c) measurement equipment. The students' uniform should also be accordance with Yamaha mechanical standards. The practical equipment facilities in the Yamaha Special Class in SMK PIRI 1 Yogyakarta has met all of the Yamaha standards.

Furthermore, one of the determinants of successful teaching and learning process is the competence of teachers because teachers are the main actors in the teaching-learning process. Nurcahyo \& Kartowagiran (2015) explain that a teacher is a key success of education because a teacher interacts directly with the students through learning activities. The teacher quality will determine the quality of the graduates as educational output. The teachers of Yamaha special class are well prepared. They are selected from the Light Vehicle Engineering teachers who are then required to attend education and training at Yamaha Motor Kencana Indonesia. They should also follow a one-day seminar about Yamaha technology inviting speakers from Yamaha.

In addition to providing equipment, the industry partner is also involved in the development of teaching materials both theoretical and practical materials. The learning process in the class is adapted from Yamaha Training Academy in Jakarta characterized by air-conditioned classrooms, standardized practice rooms and instructors who have attended training at Yamaha Motor Kencana Indonesia Jakarta. The proportion of time in the learning process is 8 hours per week for Level II (for 1 year) and 6 hours per week for Level III (for 1 year). The composition between theoretical and practical learning is $40 \%$ and $60 \%$. The government curriculum of Light Vehicle Engineering and Yamaha industry standard curriculum are implemented alternately in the morning and the afternoon.

Industry practice and industry internships for students are essential parts of vocational education in (1) producing professional-skilled workers with knowledge, skills and work ethics 
relevant to job demands, (2) enhancing and strengthening link and match between educational institutions and vocational training with the world of work, (3) improving the efficiency of providing professional quality education and training by utilizing existing training resources in the world of work, and (4) providing recognition and appreciation of work experience as part of the education process (Djojonegoro, 1999 in Muliati, 2008).

The practice in the Yamaha special class in SMK PIRI 1 Yogyakarta is followed by $11^{\text {th }}$ graders in the even semester, while the industry internship is followed by $11^{\text {th }}$ graders of the odd semester. The industry practice and the industry apprenticeship are conducted in Yamaha's authorized workshops. The duration of industry practice is 2 months. It is conducted together with the regular classes. Yamaha special class students get special priority to be accepted by all workshops under Yamaha Motor Kencana Indonesia (YMKI) to do industry practice or internships.

The procedures of industry practice are as follows: before the implementation of the industry practice in Yamaha authorized workshops, the prospective students received socialization from Yamaha. Yamaha also contacts all workshops to be used for industry practices. In addition, students also received a briefing and cover letters from the school.

The supervision of the class is conducted by Yamaha Motor Kencana Indonesia Semarang administrating a competency test at the end of level III. The competency test results will be a performance report in organizing the industry standard class from the school to the industry partner. The place of competency test is at the school. It is conducted after the national examination whose schedule is determined by the school then proposed to Yamaha Motor Kencana Indonesia Semarang. Costs related to the implementation of competency tests for the consumption of participants, committees, assessors and test equipment are all provided by the industry partner. The competency test includes theories and practical learning. All questions are confidential and prepared by the industry partner. The assessors or examiners come from the business and industry world. The school partner only helps to prepare the equipment and to oversee the test.

The implementation of the industry standard class in the Department of Light Vehicle Engineering SMK PIRI 1 Yogyakarta is a form of partnership between SMK and the industry that gives positive impact and benefits for all parties, both VHS, the industry and the students. The organization of industry standard class at SMK PIRI 1 Yogyakarta is started with the student selection process which is conducted in the third semester. The student selection process aims to recruit the students with high interest and high academic ability and skills.

The second stage is the implementation of teaching and learning process which is implemented from the third semester to the $6^{\text {th }}$ semester. The implementation of teaching and learning process including the requirements of the teachers, classroom, learning equipment, and teaching materials are all Yamaha industry standardized. The third stage is a competency test conducted at the end of the learning process in the sixth semester. The students enrolled in this class will have to perform two types of competency tests, from the government and the industry partner. The students who pass both of the competency tests will also be certified by the government and the industry partner.

A strong relationship between vocational education institution and the industries should be maintained thus the school can balance and adapt fast technological developments in the industry. Other vocational schools should also establish partnerships with the industries to organize industry standard classes since it is beneficial for all parties, particularly for the students. The Directorate General of Vocational High School should support the class by developing a system or a policy to invite the industries to build more partnerships with vocational education institutions. 


\section{CONCLUSION}

The management of the industry standard class at SMK PIRI 1 Yogyakarta generally has appropriately conducted as follows: (1) the class is planned by SMK PIRI 1 Yogyakarta by involving the industry partner in essential stages that includes curriculum development by synchronizing the industry curriculum with the government curriculum, students selection process, preparation of facilities and infrastructure, teachers' competence and teaching materials, (2) the implementation of the industry standard class is different from the regular class. The learning process is all standardized by the industry partner. Teaching materials, practical materials, practical tools, classroom and workshop facilities are provided by the industry partner. The implementation of learning is conducted by the teachers of the school but the supervision is conducted by the industry partner in the form of competency tests, (3) the supervision involves the industry partner in the form of evaluation and standardization by the industry partner. Evaluation and standardization were conducted in the form of industry standard competence tests and awarding competency certificates, (4) the model of the industry standard class management consists of three sequenced stages namely selecting the students to enroll in the class in the third semester, implementing industry standardized teaching and learning process from the third semester to the sixth semester, administrating a competency test in the sixth semester. The students of the industry standard class perform two types of competency tests and receive two certificates from the government and from the industry partner.

\section{REFERENCES}

Djoyonegoro, W. 1988. Pengembangan Sumber Daya Manusia melalui Sekolah Menengah Kejuruan. Jakarta: PT Jayakarta Agung Offset
Moleong, L. J. 2016. Metodologi Penelitian Kualitatif. Bandung: Remaja Rosdakarya

Mulyadi, Y. \& Sumarto. 2009. The Challenges and Risk of Development Vocational Education in Indonesia. Journal of Technical Education and Training. 1.1, 67-72

Nurcahyo, R. W. \& Kartowagiran, B. 2015. Praktik Pengalaman Lapangan dan Dampaknya terhadap Kompetensi Mahasiswa Class Studi Teknik Informatika dan Komputer. Jurnal Pendidikan Vokasi. 5.2, 236-247

Poerwandari E.K. 1998. Pendekatan Kualitatif dalam Penelitian Psikologi. Jakarta: LPSP3 FP-UI

Rochmadi, S. 2016. Industry Partnerships Learning Models for Surveying and Mapping of Vocational High Schools. Jurnal Pendidikan Teknologi dan Kejuruan. 23.2, 210 - 225

Sugiyono. 2015. Memahami Penelitian Kualitatif. Bandung: CV Alfabeta

Soeprijanto. 2010. Pengukuran kinerja guru praktek kejuruan. Jakarta: CV Tursina

Undang-Undang. 2003. Undang-Undang No 20 Tahun 2003 tentang Sistem Pendidikan Nasional

Wibowo, N. 2016. Upaya Memperkecil Kesenjangan Kompetensi Lulusan Sekolah Menengah Kejuruan dengan Tuntutan Dunia Industri. Jurnal Pendidikan Teknologi dan Kejuruan. 23.1, 45-49 